\title{
Jerzy Ochmański, Administracja świadcząca. Kształtowanie się idei organizatorskiej funkcji państwa w Polsce Ludowej (1944- -1989), Wyd. Naukowe UAM, Poznań 2006, 268 stron.
}

Prezentowana praca ma dwie warstwy: historycznoprawną oraz prawnoadministracyjną mocno wkraczającą w teorię prawa. Rozłożenie akcentów obu sfer nie jest jednakowe, co nie powinno bynajmniej zabrzmieć jak zarzut, aczkolwiek historyk prawa z natury chętnie widziałby rozbudowę warstwy historycznej, której jest mniej. Szczególnie część pierwsza (nieformalnie rzecz ujmując, gdyż tekst nie jest podzielony na części) ma silne cechy historycznoprawne (rozdziały I-III). Obszerny wstęp zawiera zarówno wywody z zakresu historii doktryn politycznych i prawnych, jak też własne stanowisko naukowe Autora w przedmiocie oceny i zakwalifikowania ustroju Polski Ludowej. Przy okazji: Autor używa sformułowania „socjalistycznej Polski” (s. 19), podczas gdy ja wolę użyć nazwy „Polska Ludowa”, bowiem określenie, iż w latach 1944-1989 była ona socjalistyczna budzi moje co najmniej rozterki, a nawet zastrzeżenia. Już lepszy wydaje mi się termin z dodatkiem "realny” - socjalizm realny, jak to trafnie formułuje Autor zaraz w pierwszym zdaniu rozprawy (s. 7). Ja osobiście śmielej używałbym też określenia komunizm, komunistyczna władza itp. Wiem jednak, że to wszystko bardzo dyskusyjne i Autor ma prawo do stosowania terminologii takiej właśnie, jak to przyjął. Zgadzam się natomiast w pełni z Autorem i nawet w pełni wspieram Go w Jego stanowisku, iż dla charakterystyki ustroju Polski Ludowej w całym okresie 1944-1989 należy przyjąć, iż był to system totalitarny. Totalitaryzm niedoskonały, totalitaryzm kulejący i z biegiem czasu kruszący się, ale jednak totalitaryzm. Autor skrótowo przedstawił w kwestii istoty totalitaryzmu rozmaite poglądy, od Hannah Arendt oraz Carla Friedricha i Zbigniewa Brzezinskiego poczynając, na Janie Baszkiewiczu i Andrzeju Walickim kończąc. Na ten temat można pisać całe książki, a nawet trzeba jeszcze pisać niejedną książkę i dlatego w tym miejscu nie można nad kwestią się zatrzymywać.

Obok wstępu, najmocniej aspekty historycznoprawne zawiera rozdział pierwszy, poświęcony roli państwa socjalistycznego w zaspokajaniu potrzeb; Autor porusza się tutaj w obszarze historii doktryn politycznych i prawnych. Prezentację charakterystyki rozwoju państwa socjalistycznego w ujęciu klasyków i ideologów marksizmu (marksizmu-leninizmu) czyta się dobrze. Nawet jeśli niektóre wywody stanowią jedynie zebranie dotychczasowych ustaleń nauki, to jednak syntetyczne ich przedstawienie ma swoją wartość. Ta część pracy jest dobrym wprowadzeniem do zagadnienia zaspokajania potrzeb przez państwo, a zwłaszcza przez państwo tzw. socjalistyczne, co z kolei stanowi wstęp do zagadnień administracji świadczącej.

Podobnie dobrze osadzone w dziejach Polski Ludowej rozważania prowadzi Autor jeszcze w rozdziałach drugim i trzecim, gdy omawia kierowniczą rolę partii komunistycznej w teorii i trochę w praktyce, gdy - nader interesująco - pokazuje w tej materii 
wspomaganie partii przez niektórych uczonych. Podobnie dalsze części, np. poświęcone zagadnieniu demokracji socjalistycznej (demokratyzmu socjalistycznego), centralizmu demokratycznego i inne. I tu wyraźnie widać, że zarówno suflerami dla władzy, jak i spieszącymi z „naukowymi” potwierdzeniami „jedynie słusznej linii” byli uczeni o znanych, czołowych nazwiskach. Taka była rzeczywistość owych czasów (zwłaszcza okresu tzw. stalinowskiego, tj. przed październikiem 1956 r.).

Rzeczywistością było, iż - w sposób nieunikniony - nauka prawa administracyjnego należała do najbardziej spętanych przez politykę, a więc - w konsekwencji - stała się szczególnie służebna wobec minionego reżimu, uzasadniała go. Z recenzowanej rozprawy widać, że długo uzasadniała wytrwale, nieraz skrupulatnie i z zaangażowaniem, ale widać też wyraźnie, iż z biegiem czasu przybywało ludzi i postaw próbujących w ówczesnych realiach kształtować rozwiązania liberalne, nowoczesne, nacechowane myślą o zabezpieczeniu praw człowieka; pojawiali się ludzie, którzy w otoczce frazeologii marksistowskiej przemycali cywilizowane rozwiązania. To dobra strona całej pracy.

Dalsze partie monografii Jerzego Ochmańskiego mają jak gdyby nieco słabszą otoczkę historycznoprawną. Autor koncentruje swoją uwagę bardziej na kwestiach teorii prawa oraz konstrukcji i pojęć z zakresu prawa administracyjnego.

Praca jest unikatowa, w tym znaczeniu, że dotyczy zagadnień w literaturze naukowej pod kątem historycznoprawnym zupełnie nietkniętych. Warto, by dalsze badania nad historią prawa Polski Ludowej m.in. poszły analogiczną drogą. 